Article

\title{
Social Life Cycle Assessment of Brine Treatment in the Process Industry: A Consequential Approach Case Study
}

\author{
Georgios Archimidis Tsalidis *(D) and Gijsbert Korevaar $\mathbb{B}$ \\ Engineering Systems and Services department, Faculty of Technology, Policy, and Management Delft University \\ of Technology, Jaffalaan 5, 2628 BX Delft, The Netherland; g.korevaar@tudelft.nl \\ * Correspondence: g.a.tsalidis@tudelft.nl
}

Received: 1 April 2019; Accepted: 18 October 2019; Published: 25 October 2019

check for updates

\begin{abstract}
Social life cycle assessment (SLCA) was developed to complement the environmental life cycle assessment (LCA) and economic assessment. Contrary to LCA, SLCA is not yet standardized, and the consequential approach is little discussed in literature. This study aims to perform a consequential SLCA and investigate the applicability of the method in industrial decision making. The aforementioned assessment is done within the Zero Brine project, which works on zero liquid discharge technology for water, salt, and magnesium recovery from brine effluents. The developed SLCA systems are gate-to-gate, and the analysis is performed at two levels: Hotspot and site-specific. The system boundaries consist of a demineralized water (DW) production company, a chlor-alkali company, an electricity provider, a magnesium distributor in the Netherlands, and a Russian mining company. The latter exists only in the boundaries before the change due to the Zero Brine project, because recovered magnesium is expected to replace the Russian magnesium imported in the Netherlands. Within the system boundaries, the stakeholders contributing the most are the DW and the magnesium distributor companies. The former produces the brine and thus recovers the magnesium and salt. The latter is the exclusive distributor of Russian magnesium in the Netherlands. Overall, we find that the recovered magnesium results in improving social performance mainly in "Freedom of association and collective bargaining", "Fair salary", and "Health and Safety" due to decreasing the dependency of the Netherlands on Russia, while increasing operation in a country with much stronger environmental regulation and corporate commitment to sustainability issues. Modelling with SLCA may not result in the expected societal benefits, as the Russian community and workers may not benefit due to the large geographical boundaries of the system under study. Nevertheless, the application of the consequential approach can be considered suitable, yet complicated, for offering decision makers adequate social information. We recommend that decision makers in the DW company invest in magnesium recovery and that decision makers in the magnesium distributor company distribute the recovered magnesium.
\end{abstract}

Keywords: social life cycle assessment; brine; process industry; magnesium; consequential approach

\section{Introduction}

The environmental and economic aspects of the process industry have been investigated thoroughly with different methods, such as life cycle assessment (LCA) and techno-economic analysis. However, the societal performance with Social Life Cycle Assessment (SLCA) of the process industry is little discussed in literature. So far, SLCA practitioners have solely focused on modelling within a chosen temporal window. Therefore, the focus of this study is the first use of SLCA for modelling the societal impact change in response to decisions for brine treatment within the process industry in the port of Rotterdam. 
Industrial brine is a high-concentration solution of salt in water and waste produced in large amounts. Its disposal is, on one hand, problematic due to the environmental degradation of water bodies resulting in the increasing salinity level and its content in critical raw materials [1] and, on the other hand, challenging in eliminating the contained metal elements [2]. The European Directive on Waste [3] mandates member countries to address waste and byproduct reuse [4]. Furthermore, industrial brine contains materials that the European Union has identified as critical raw materials [1], such as magnesium [5], and has prioritised them in the Circular Economy Package. Magnesium shows both a high supply risk and economic importance [6,7] as all available processed magnesium is imported to Europe mainly from far eastern Russia or China. Therefore, the need for a solution to environmental and raw material problems led to the development of sophisticated brine disposal methods. One of these methods actually improves water recovery to the highest level while reducing brine. This method is called Zero Liquid Discharge (ZLD) and currently represents state-of-the-art technology [8]. ZLD technology eliminates brine disposal via its conversion to highly pure water (95-99\% water recovery) and salt. It typically consists of a preconcentration stage based on membrane-based technologies, evaporation, and crystallization mainly based on thermal-based technologies, which enable the industry to conform to regulations [9]. The preconcentrating stage (for instance, filtration) is easy to use in waste water treatment plants [10] and vital for the following two stages. On the other hand, the cost of thermal-based technologies can become a burden for a system employing ZLD. Therefore, benefits should be achieved in other aspects of the system that employs ZLD, such as environmental, social, regulatory, etc. The Zero Brine project aims at applying the ZLD technology in a demineralized water plant (coded as DW) in the port of Rotterdam, in the Netherlands, to recover clean water, sodium salt, and magnesium.

Mining in Russia has a distinct characteristic. Modern Russian traditions are still influenced by more than 70 years of communist rule and ideology (1917-1991). Among the surviving traditions of that period is an authoritarian type of governance, some weak civil society institutions, and some underdeveloped democratic decision-making procedures [11]. Therefore, companies do not necessarily need to secure social acceptance to make tough decisions with major consequences. In Russian company towns, such as Kuldur where the magnesium mining occurs, negative environmental impacts from mining companies are offset by job creation and social services provided by the same companies [12].

The 2005 World Summit on Social Development [13] identified sustainable development goals based on the three aspects of sustainability, i.e., economic development, social development, and environmental protection. The environmental, economic, and social facets can be evaluated with LCA, life cycle costing, and SLCA, respectively. Unlike LCA, SLCA is not yet standardized, and researchers are not consistent in using indicators. As a result, various social indicators have been used in literature, and SLCA is still undergoing evolution [14-17]. SLCA follows the same framework as the LCA method, from the goal and scope definition phase to the life cycle inventory, the life cycle impact assessment, and interpretation phases [18-22]. SLCA is described as "a social impact assessment technique that aims to assess the social and socio-economic aspects of products and their potential positive and negative impacts along their life cycle" [19]. Therefore, researchers suggest that decision-making based on the SLCA method leads to more beneficial situations for the society [23] and general sustainability.

Similar to LCA, SLCA has been used following the attributional and consequential modelling approaches. The attributional approach aims to show: "How are environmental releases flowing within the chosen temporal window?" [24], whereas the consequential one aims to show: "How will flows change in response to decisions?" [24]. The majority of the SLCA studies use the attributional approach as researchers model product systems and identify hotspots [25]. Nevertheless, increasing the discussion of consequential SLCA has been pointed out as a strategic point for the methodology development [15]. Contrary to LCA, the SLCA guidelines describe two levels of analysis: A hotspot and a site-specific level. Hotspot level of analysis consists of data more generic to the case study, while the site-specific level consists of data collected from the involved stakeholders. A hotspot level 
is considered when the aim is conducting a generic assessment of a type of product, for example. In this case, a specific supply chain would not be considered and generic data would be used, such as data available for the country, region, or sector. On the other hand, a site-specific level is considered when the aim is a specific product and a specific company. Then, data collection is performed through social audits. Recently, the United Nations Environment Programme and the Society of Environmental Toxicology and Chemistry published the methodological sheets that consist of a set of hotspot and site-specific indicators [18].

Due to the absence of standardized indicators for SLCA, researchers focus heavily on workerand health-related indicators. Empirical SLCA studies have mainly addressed the manufacturing and utilities industrial sectors. As far as the manufacturing sector is concerned, the chemical manufacturing is dominating the studies [17]. These studies focus on biomass-based production of fuel, while researchers often develop social indicator frameworks for their social assessments [17,26,27]. In addition, the social performance of chemical industry was assessed though Product Social Impact Assessment [28]. So far, only two studies [21,29] have used SLCA to analyze the societal performance of water systems, but both of them concerned drinking water systems. Lehman et al. [21] performed their study on the hotspot analysis level for plants for water supply and fuel conversion. Similarly, Opher et al. [29] performed their analysis on the site-specific level for municipal services for reuse of domestic wastewater. Therefore, evaluating the process industry that produces feedstock for the chlor-alkali industry in the Netherlands is missing from SLCA literature.

Remodifying the water treatment train of a DW plant is expected to result in recovering clean water, salt, and magnesium. Such a modification can be modelled with LCA and LCC methods in order for the DW company to decide whether to invest or not. That would constitute applying the consequential LCA modelling approach. Therefore, we use the same approach for performing SLCA and investigating the applicability of it in decision making. The aim of this study is to use the SLCA on the hotspot and site-specific levels to quantify, for the first time, the societal effects of recovering magnesium in a DW company's plant instead of importing it from Russia.

\section{Materials and Methods}

The SLCA method follows the same framework as the LCA method, from the goal and scope to life cycle inventory, to life cycle assessment, and interpretation [19]. Firstly, the system under study is described in terms of aim, assumptions, and system boundaries. Secondly, data are collected and organized. Data exist on two levels: Generic data and site-specific data. The former can be used for societal "hotspots" identification, whereas the latter concerns data about specific stakeholders. The guidelines [19] suggest the collection of site-specific data or a combination of both kinds when needed. In this study, we decided to use both kinds in order to have a better overview of the social performance. Thirdly, based on the data, impact subcategories are characterized and aggregated to impact categories and stakeholder groups. Lastly, results are discussed and conclusions are presented.

\subsection{Case Study: Zero Brine}

\subsubsection{Goal and Scope Definition}

The case study concerns the societal performance of the demineralized water plant company (coded as DW) at the port of Rotterdam. DW produces ultra-pure demineralized water for the neighbouring process industry. Consequently, based on the functionality of the system and the recovery due to changes in the brine treatment, the functional unit is " $1400 \mathrm{~m}^{3}$ of ultra-pure demineralized water, $114 \mathrm{~kg}$ salt, and $0.92 \mathrm{~kg}$ magnesium", which corresponds to the capacity of the DW plant and recovered magnesium per hour, respectively. The recovered salt and magnesium will replace the high-purity salt purchased by a chlor-alkali company, and the magnesium mined in far eastern Russia by a Russian mining company before it gets distributed by a magnesium distributor company. It is worth mentioning that the Russian deposit is mined with the open pit method under explosion with external stacking. 
SLCA guidelines $[15,19]$ suggest prioritizing and limiting the system boundaries to foreground sub-systems only. Figure 1 illustrates the system boundaries, and Table 1 presents the type of connection of the stakeholders in the system boundaries. In Figure 1, Chlor-Alkali 1 concerns the high-purity salt produced in Delfzijl, while Chlor-Alkali 2 concerns the chlor-alkali company operating in the port of Rotterdam for chlorine production. The system boundaries start with water pumped to the DW from the Breelse Lake and processed to produce ultra-pure demineralized water and brine. The lake water is processed firstly with coagulation and floatation processes, filtration, and then with ion exchange (IEX) softening and reverse osmosis. Lastly, a mixed bed polisher is used before distributing the demineralized water to the water network. Both the IEX softener and reverse osmosis unit produce brine, i.e., site 1 and site 2. Based on the modifications, used salt from chlor-alkali plant 1 will be recovered and consumed in the DW plant, and magnesium will be recovered and sold in the Netherlands. All Dutch stakeholders are related through either mass, energy, or monetary flows. On the other hand, the Russian mining company is only connected to the magnesium distributor company, as it is the exclusive distributor in the Netherlands. Therefore, the system boundaries consist of two levels: Regional and national.

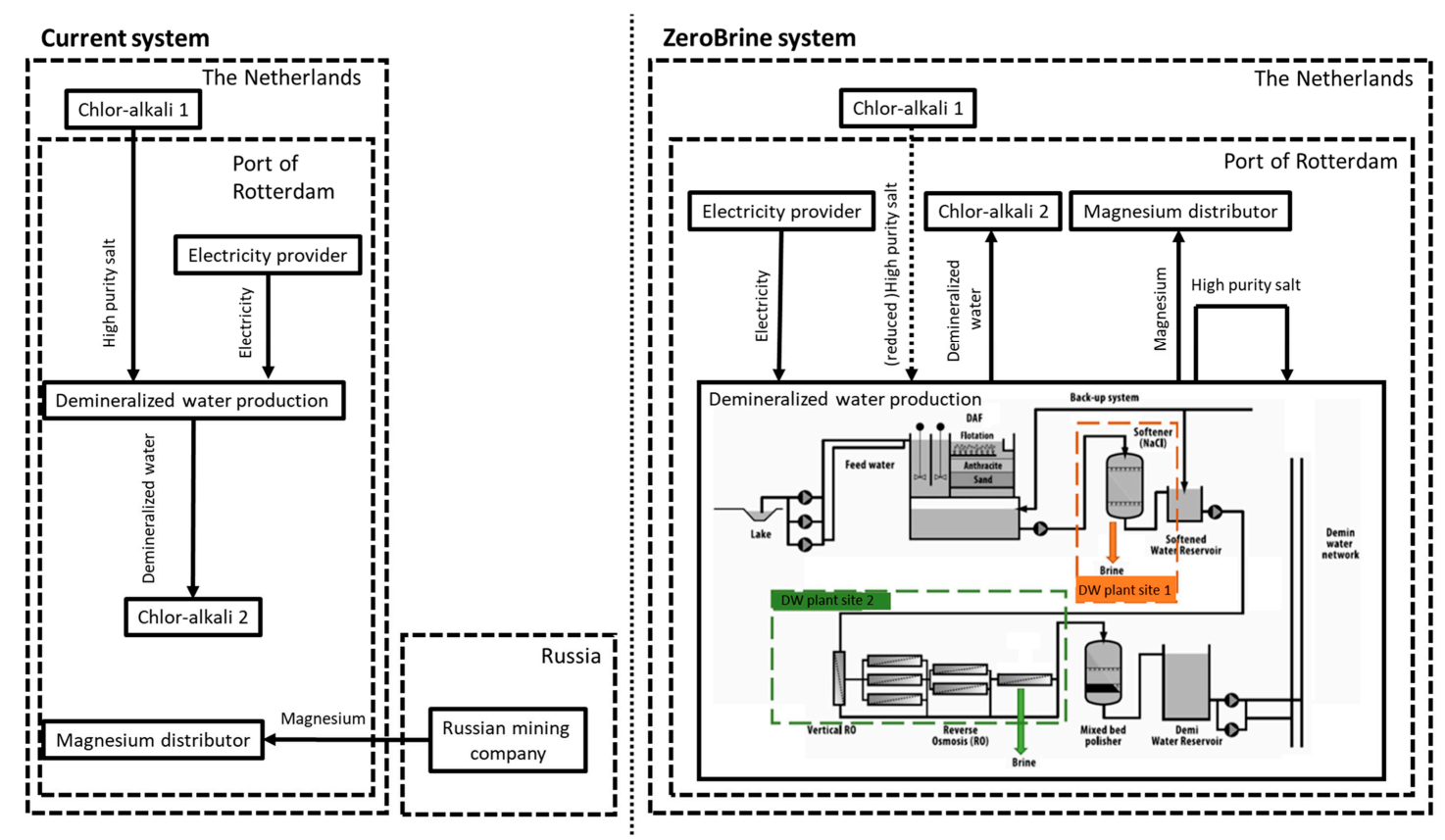

Figure 1. Social Life Cycle Assessment (SLCA) boundaries of current system and Zero Brine system (after change).

Table 1. Relationships/Flows among Involved Stakeholders.

\begin{tabular}{cccccc}
\hline $\begin{array}{c}\text { Stakeholder } \\
\text { Relationships }\end{array}$ & DW & $\begin{array}{c}\text { Chlor-Alkali } \\
\mathbf{1} \text { and 2 }\end{array}$ & $\begin{array}{c}\text { Magnesium } \\
\text { Distributor }\end{array}$ & $\begin{array}{c}\text { Electricity } \\
\text { Provider }\end{array}$ & $\begin{array}{c}\text { Russian Mining } \\
\text { Company }\end{array}$ \\
\hline DWP & 1 & Mass & Mass & Energy & - \\
\hline Chlor-alkali plant & Mass & 1 & - & Energy & - \\
\hline Magnesium distributor & Mass & - & 1 & - & Mass \\
\hline Electricity provider & Energy & Energy & - & - & 1 \\
\hline $\begin{array}{c}\text { Russian mining } \\
\text { company }\end{array}$ & - & - & Mass & - & \\
\hline
\end{tabular}

SLCA consists of five stakeholder groups: The local community, value chain actors, consumer, worker, and society. Due to the system boundaries and aim of this study, all the stakeholder groups and impact categories were considered of equal importance and selected for the hotspot analysis 
level. Significant differences were expected between the Netherlands and Russia in terms of how the chemical industry in these two countries treats the five stakeholder groups. It was not possible to include all subcategories, as no reliable data existed for each subcategory, so we tried to focus on quantitative data for hotspots analysis and qualitative data for site-specific analysis. Ultimately, at least one subcategory was considered per impact category. The only exceptions regarded the "Local employment", the "Cultural heritage", the "Fair competition", and the "Technology development" impact categories because it was not possible to collect information for both systems on the hotspot analysis level, or it was out of the scope of this study. In addition, concerning the site-specific analysis level, we considered impact categories and subcategories based on how the involved companies treated all stakeholder groups in relation to data availability.

\subsubsection{Life Cycle Inventory Analysis}

Data Collection and Assessment of Subcategories

A hotspot analysis provides information on in which area the issues of concern may be the most significant in the product's life cycle. It typically concerns the one where the largest input to the life cycle of the product comes from [19]. The hotspot analysis started with the selection of the country and sector. This study focused on two countries: The Netherlands and Russia. Data collection was performed through international organizations and official national statistical data sources. The site-specific analysis focused on six companies: Five involved companies in the Dutch chemical industry, and one Russian mining company. Data collection was performed through personal interviews with the involved companies and corporate social responsibility reports, except for data collection for the Russian mining company, which was performed through Russian public documents (e.g., local newspapers) as the Russian mining company didn't publish any corporate social responsibility or annual reports at all. In addition, the mining sector worldwide has not improved, according to those living closest to the mines and, consequently, most affected [30]. As a result, information from international literature [12,31-35] and English translations of interviews [36-38] of the Russian mining company director was collected and analysed.

Data collection from national reports, international statistical organizations, and interviews corresponds to the years 2014-2017, except for "country privacy ranking", which corresponds to 2007. In order to perform the characterization step for the next SLCA phase, summarizing qualitative data and summing up quantitative data are needed. To facilitate this procedure, a scoring system is helpful. In the guidelines, no specific aggregating methods are recommended. Alternatively, two general types of SLCA methods are pointed out: 1) Type 1 SLCA methods, which use Performance Reference Points (PRPs), and 2) Type 2 SLCA methods, which attempt to seek the cause-and-effect relations between indicators and social impacts. The main difference between the two methods is the scoring system in Type 1 methods $[39,40]$. Type 1 SLCA methods qualify data that correspond to positive or negative (or a variation between the two extremes) social sustainability performance and aggregate the results for subcategories through a scoring system [41], while Type 2 SLCA models the results for subcategories that have a causal relationship; for instance, the relation between income level and health status. In this study, for characterization, we applied a modified version of PROSA guidelines [42] in order to assign "value $=3$ " to "no data". This is the same value as "indifferent effects", but it is illustrated with a different colour, therefore using a grading scale of 1-9, as shown in Figure 2.

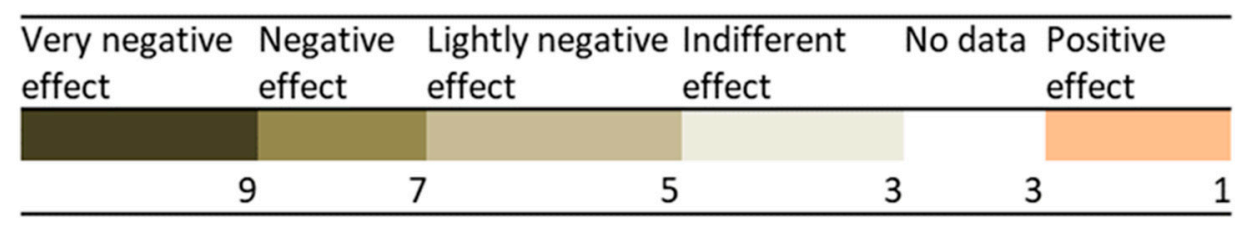

Figure 2. Scoring scheme for social hotspot inventory indicators. 
Activity Variable

An activity variable measures process activity or scale that can be related to a process output. Activity variables represent the product system in a way that gives an idea of the relative significance of each unit process in the whole system. The purpose of the activity variable is to refine the results by considering which parts of the product system contribute the most to the results and, therefore, the largest potential impact on stakeholder groups [19]. The SLCA guidelines [19] suggest two activity variables: Working time and added value. The former is the most frequently used variable to address scoring $[43,44]$. Thus, the coefficient of working time (i.e., hours of work per FU) was used for weighting the societal aspects of the processes. Table 2 shows that due to the different capacities of involved stakeholders, the main contributor to the societal performance would be a DW plant. The calculation for the coefficients was based on the following formula and can be found in Supplementary Material:

$$
\text { Activity Variable }(h)=\frac{C O N_{X}}{C P_{x}}
$$

CON: Consumption of product $X$ based on functional unit

$\mathrm{C}$ : Capacity of producing product $\mathrm{X}$ per hour

Table 2. Coefficients of working time in "hours of work" per FU.

\begin{tabular}{cccccc}
\hline & DW Company & $\begin{array}{c}\text { Chlor-Alkali } \\
\text { Company }\end{array}$ & $\begin{array}{c}\text { Electricity } \\
\text { Provider }\end{array}$ & $\begin{array}{c}\text { Magnesium } \\
\text { Distributor }\end{array}$ & $\begin{array}{c}\text { Russian Mining } \\
\text { Company }\end{array}$ \\
\hline Coefficient $(\mathrm{h})$ & 1 & 0.0002 & 0.007 & 0.15 & 0.53 \\
\hline
\end{tabular}

\section{Results and Discussion}

\subsection{Life Cycle Impact Assessment and Interpretation}

The scoring scheme in Figure 2 can be used to quickly identify societal issues that need attention, as shown in Tables 3 and 4. In Table 3, cells with positive effects indicate a hotspot in terms of safe situations, cells with very negative or negative effects indicate a hotspot in terms of risky situations, and cells with lightly negative or indifferent effects may be dropped from further analysis. According to the sources considered, Table 3 shows more major societal risks in Russia than in the Netherlands, with the main affected groups being the local community and workers. For most of the indicators, the differences range within one level (e.g., from lightly negative to negative). Russia is associated with a multitude of societal issues regarding the exploitation of workers (based on "Hours of work", "Forced labour"), "Freedom of expression", and "Corruption" due to the legal framework for mining having significant weaknesses [35]. For these indicators, the differences between the two countries are bigger than one level in the scoring scale, and these results are in agreement with a recent study by Di Noi et al. [45], which showed that the European mining sector results in high social risks, corruption, and treatment of workers, such as fair salary and freedom of association and collective bargaining. Furthermore, reducing the import of Russian magnesium will result in reducing imports from a conflicted country, which coincides with the challenge the European Union is already tackling against conflict-free sourcing minerals [46]. Russia scores very low on the peace index, in contrast with the Netherlands [47]. On the other hand, the Netherlands induces mainly positive societal impacts, such as "Public commitment to sustainability issues", "Contribution to economic development", and "Access to material and immaterial resources". In general, Netherlands offers a more stable environment for businesses to innovate and it scores better than Russia in indicators regarding the citizens' wellbeing. In addition, the Netherlands is a big importer of goods (in terms of products' value). Therefore, recovering magnesium from waste effluents would increase independence from international suppliers with identified societal risks. 
Table 3. The results of hotspot analysis for the Netherlands and Russia.

\begin{tabular}{|c|c|c|c|c|}
\hline Stakeholder Categories & Impact Categories & Hotspots Inventory Indicators & Netherlands & Russia \\
\hline \multirow{15}{*}{ Local community } & \multirow[t]{2}{*}{ Delocalization and migration $^{\text {a }}$} & \multirow{2}{*}{$\begin{array}{c}\text { International Migrants as a Percentage of Population } \\
\text { Public Trust of Politicians }\end{array}$} & 3 & 3 \\
\hline & & & 5 & 5 \\
\hline & \multirow{2}{*}{ Community engagement ${ }^{b}$} & Freedom of Peaceful Assembly and Association & 3 & 5 \\
\hline & & Transparency of Government Policymaking & 1 & 7 \\
\hline & \multirow{2}{*}{ Respect of indigenous rights ${ }^{c}$} & Human Rights Issues Faced by Indigenous Peoples & 3 & 3 \\
\hline & & Indigenous Land Rights Conflicts/Land Claims & 1 & 7 \\
\hline & \multirow{3}{*}{ Access to immaterial resources ${ }^{d}$} & Freedom of Expression in Country of Operation & 1 & 9 \\
\hline & & Levels of Technology Transfer & 1 & 7 \\
\hline & & Extraction of Material Resources & 5 & 7 \\
\hline & \multirow{3}{*}{ Access to material resources ${ }^{e}$} & Levels of Industrial Water Use & 5 & 3 \\
\hline & & $\begin{array}{l}\text { Percentage of Population (Urban, Rural, Total) with } \\
\text { Access to Improved Sanitation Facilities }\end{array}$ & 1 & 5 \\
\hline & & Burden of Disease by Country & 1 & 3 \\
\hline & \multirow[t]{2}{*}{ Safe and healthy living conditions ${ }^{f}$} & Pollution Levels by Country & 1 & 1 \\
\hline & & $\begin{array}{c}\text { Presence/Strength of Laws on Construction Safety } \\
\text { Regulations by Country }\end{array}$ & 5 & 5 \\
\hline & Secure living conditions $\mathrm{g}$ & Strength of Public Security in Country of Operation & 5 & 7 \\
\hline & Total & & 38 & 76 \\
\hline \multirow[t]{2}{*}{ Value chain actors } & Respect of intellectual property rights ${ }^{h}$ & $\begin{array}{c}\text { General intellectual property rights and related issues } \\
\text { associated with the economic sector }\end{array}$ & 1 & 3 \\
\hline & Promoting social responsibility ${ }^{i}$ & Industry code of conduct in the sector & 1 & 3 \\
\hline & Total & & 2 & 6 \\
\hline \multirow{5}{*}{ Consumer } & Feedback mechanism $j$ & Presence of feedback mechanisms & 1 & 1 \\
\hline & Privacy $k$ & Country privacy ranking & 3 & 5 \\
\hline & Transparency $^{1}$ & $\begin{array}{c}\text { Presence of a law or norm regarding transparency (by } \\
\text { country and/or sector) }\end{array}$ & 3 & 3 \\
\hline & & $\begin{array}{l}\text { Sector transparency rating; number of organizations by } \\
\text { sector that published a sustainability report }\end{array}$ & 3 & 3 \\
\hline & End-of-life responsibility ${ }^{\mathrm{m}}$ & $\begin{array}{l}\text { Strength of national legislation covering product disposal } \\
\text { and recycling }\end{array}$ & 3 & 3 \\
\hline
\end{tabular}


Table 3. Cont.

\begin{tabular}{|c|c|c|c|c|}
\hline Stakeholder Categories & Impact Categories & Hotspots Inventory Indicators & Netherlands & Russia \\
\hline & Total & & 13 & 15 \\
\hline \multirow{12}{*}{ Worker } & \multirow{3}{*}{$\begin{array}{l}\text { Freedom of association and } \\
\text { collective bargaining }{ }^{n}\end{array}$} & $\begin{array}{c}\text { Evidence of restriction to freedom of association and } \\
\text { collective bargaining }\end{array}$ & 3 & 9 \\
\hline & & $\begin{array}{c}\text { Evidence of country/sector/organization or factory } \\
\text { disrespect or support to freedom of association and } \\
\text { collective bargaining }\end{array}$ & 3 & 9 \\
\hline & & $\begin{array}{l}\text { GRI: HR4 operations identified in which the right to } \\
\text { exercise freedom of association and collective bargaining } \\
\text { may be at significant risk, and actions taken to support } \\
\text { these rights }\end{array}$ & 3 & 7 \\
\hline & Fair salary ${ }^{\circ}$ & Minimum wage by country (Euros) & 5 & 7 \\
\hline & Hours of work $p$ & Excessive Hours of work & 1 & 1 \\
\hline & Child labour ${ }^{q}$ & Percentage of children working by country & 1 & 1 \\
\hline & \multirow{2}{*}{ Forced labour ${ }^{r}$} & Percentage (estimate) of forced labour by region & 3 & 9 \\
\hline & & Government response rating to modern slavery & 7 & 9 \\
\hline & \multirow{2}{*}{ Equal opportunities $s$} & Women in the Labor force participation rate by country & 3 & 3 \\
\hline & & Country gender index ranking & 3 & 7 \\
\hline & Health and safety ${ }^{t}$ & Occupational accident rate by country or sector & 1 & 3 \\
\hline & Social benefit/social security ${ }^{u}$ & $\begin{array}{l}\text { Social security expenditure by country and branches of } \\
\text { social security }\end{array}$ & 3 & 3 \\
\hline & Total & & 36 & 68 \\
\hline \multirow{6}{*}{ Society } & \multirow{2}{*}{$\begin{array}{l}\text { Public commitment to } \\
\text { sustainability issues }\end{array}$} & $\begin{array}{l}\text { Existence of (legal) obligation on public } \\
\text { sustainability reporting }\end{array}$ & 1 & 3 \\
\hline & & $\begin{array}{l}\text { Engagement of the chemical sector } \\
\text { regarding sustainability }\end{array}$ & 3 & 3 \\
\hline & $\begin{array}{l}\text { Contribution to economic } \\
\text { development }{ }^{w}\end{array}$ & Economic situation of the country & 1 & 5 \\
\hline & \multirow{2}{*}{ Corruption $^{x}$} & Risk of corruption in the country and/or sub-region & 7 & 9 \\
\hline & & Risk of corruption in the sector & 1 & 7 \\
\hline & Total & & 13 & 27 \\
\hline
\end{tabular}

${ }^{\mathrm{a}}[48],{ }^{\mathrm{b}}[49,50], \mathrm{c}, \mathrm{d}[51,52],{ }^{\mathrm{e}}[52],{ }^{\mathrm{f}}[53,54], \mathrm{g}^{\mathrm{g}}[55],{ }^{\mathrm{h}}[48],{ }^{\mathrm{i}}[56], \mathrm{j}[57,58],{ }^{\mathrm{k}}[57],{ }^{\mathrm{l}}[59],{ }^{\mathrm{m}}[60],{ }^{\mathrm{n}}[61-63],{ }^{\mathrm{o}}[61,64], \mathrm{p}, \mathrm{q}, \mathrm{r}[61],{ }^{\mathrm{s}}[65],{ }^{\mathrm{t}}[61],{ }^{\mathrm{u}}[61],{ }^{\mathrm{v}}[56], \mathrm{w}[66],{ }^{\mathrm{x}}[67]$, 
Recovering salt and magnesium from brine effluents results in reducing the supply of high-purity salt from Chlor-Alkali 1 to DW (in pre DW stage) and the import of magnesium from Russia (in post-DW stage), respectively. The recoveries of salt and clean water do not result in changes in Chlor-Alkali 1 and 2 production and consumption patterns before and after the DW stage, respectively. The quantities of the recovered salt are minor compared to the production capacity of Chlor-Alkali 1 in Delfzijl. Reducing the import of mined magnesium will have social benefits as the impact of mining operations will lessen in the system boundaries. In particular, the Russian mining company is a big contributor to the financial income of the local community and a well payed employer who prefers to hire locally. However, the open pit mining, the absence of any kind of annual reporting, the fact that the company operates in a region high in conflict, and the fact that the director of the company is also the governor of the region show potential negative social impacts and conflict of interest. Therefore, recovering magnesium from brine would result in reducing Russian exporting to the Netherlands. This decision would not have a major influence on the Russian mining company as China and other European countries are also big customers.

Table 4 shows that no significant societal issues exist within the Dutch supply chain when coefficients are not considered. However, there are issues regarding negative effects on the consumer or society groups, which derive from occasional accidents or countries that the chlor-alkali company operates. Employment is expected to be affected due to magnesium and salt recovery, and all involved companies (except the Russian mining company) show positive signs. These positive results of the Dutch chemical sector are in agreement with published SLCA literature [68-71] concerning case studies in developed countries. Due to national legislation regarding consumers and workers, companies must keep high standards on how they treat these two stakeholder groups. In addition, due to national targets, companies focus on improving environmental footprints, and the chemical sector in the Netherlands publishes corporate social responsibility reports, which may increase transparency. If coefficients are considered, then DW and Russian mining companies receive the largest societal scores due to having the largest coefficients (see Table 2) and potential societal risks. The DW company's main feedstock is lake water and the amount of consumables is low (electricity and high purity salt), resulting in the DW company contributing the largest share to the post-change results due to considered coefficients. Nevertheless, the DW company scores well in individual indicators in general. On the other hand, the score of the Russian mining company is a combination of societal risks and its coefficient. In fact, the only reason that the Russian mining company does not result in the strongest pre-change impact is due to lack of data for some impact indicators. 
Table 4. Results of hotspot analysis for Evides Industriewater B.V. [72-74], AkzoNobel N.V. [75], Electrabel [76,77], Europiren B.V. [78], and Russian mining company [36,37].

\begin{tabular}{|c|c|c|c|c|c|c|c|c|}
\hline \multirow{2}{*}{$\begin{array}{l}\text { Stakeholder } \\
\text { Categories }\end{array}$} & \multirow{2}{*}{ Impact Categories } & \multirow{2}{*}{ Hotspots Inventory Indicators } & \multicolumn{2}{|c|}{ Pre-Botlek Stage } & \multirow{2}{*}{$\frac{\text { Botlek Stage }}{\text { DW }}$} & \multicolumn{2}{|c|}{ Post-Botlek Stage } & \multirow{2}{*}{$\begin{array}{l}\text { Russian } \\
\text { Mining }\end{array}$} \\
\hline & & & High Purity Salt & Electricity & & Chlor-Alkali & Magnesium & \\
\hline \multirow{3}{*}{ Local community } & \multirow{3}{*}{ Local employment } & $\begin{array}{c}\text { Percentage of workforce } \\
\text { hired locally }\end{array}$ & 1 & 3 & 1 & 1 & 5 & 1 \\
\hline & & $\begin{array}{l}\text { Strength of policies on local } \\
\text { hiring preferences }\end{array}$ & 3 & 3 & 3 & 3 & 3 & 1 \\
\hline & & $\begin{array}{l}\text { Percentage of spending on locally } \\
\text { based suppliers }\end{array}$ & 3 & 3 & 3 & 3 & 3 & 3 \\
\hline & $\begin{array}{l}\text { Total (without } \\
\text { coefficients) }\end{array}$ & & 7 & 9 & 7 & 7 & 11 & 5 \\
\hline & Total (with coefficients) & & 0.0014 & 0.063 & 7 & 0.0014 & 1.65 & 2.65 \\
\hline \multirow[t]{3}{*}{ Value chain actors } & $\begin{array}{c}\text { Promoting social } \\
\text { responsibility }\end{array}$ & $\begin{array}{l}\text { Industry code of conduct in } \\
\text { the sector }\end{array}$ & 1 & 1 & 1 & 1 & 5 & 7 \\
\hline & $\begin{array}{l}\text { Total (without } \\
\text { coefficients) }\end{array}$ & & 1 & 1 & 1 & 1 & 5 & 7 \\
\hline & Total (with coefficients) & & 0.0002 & 0.007 & 1 & 0.0002 & 0.75 & 3.71 \\
\hline \multirow{5}{*}{ Consumer } & Health and Safety & $\begin{array}{l}\text { Presence of consumer complaints } \\
\text { (at organizational level) }\end{array}$ & 5 & 5 & 5 & 5 & 3 & 3 \\
\hline & & $\begin{array}{c}\text { Quality of or number of } \\
\text { information/signs on product } \\
\text { health and safety }\end{array}$ & 1 & 1 & 1 & 1 & 1 & 5 \\
\hline & Feedback mechanism & Presence of feedback mechanisms & 1 & 1 & 1 & 1 & 1 & 1 \\
\hline & $\begin{array}{l}\text { Total (without } \\
\text { coefficients) }\end{array}$ & & 7 & 7 & 7 & 7 & 5 & 9 \\
\hline & Total (with coefficients) & & 0.0014 & 0.049 & 7 & 0.0014 & 0.75 & 4.77 \\
\hline
\end{tabular}


Table 4. Cont

\begin{tabular}{|c|c|c|c|c|c|c|c|c|}
\hline \multirow{2}{*}{$\begin{array}{l}\text { Stakeholder } \\
\text { Categories }\end{array}$} & \multirow{2}{*}{ Impact Categories } & \multirow{2}{*}{ Hotspots Inventory Indicators } & \multicolumn{2}{|c|}{ Pre-Botlek Stage } & \multirow{2}{*}{$\frac{\text { Botlek Stage }}{\text { DW }}$} & \multicolumn{2}{|c|}{ Post-Botlek Stage } & \multirow{2}{*}{$\begin{array}{l}\text { Russian } \\
\text { Mining }\end{array}$} \\
\hline & & & High Purity Salt & Electricity & & Chlor-Alkali & Magnesium & \\
\hline \multirow{6}{*}{ Worker } & Freedom of association & $\begin{array}{c}\text { Evidence of restriction to freedom } \\
\text { of association and } \\
\text { Collective bargaining }\end{array}$ & 3 & 3 & 3 & 3 & 3 & 3 \\
\hline & \multirow{4}{*}{ Child labour } & $\begin{array}{c}\text { Evidence of organization or factory } \\
\text { disrespect or support to freedom of } \\
\text { association and } \\
\text { collective bargaining }\end{array}$ & 3 & 3 & 3 & 3 & 3 & 3 \\
\hline & & $\begin{array}{l}\text { GRI: HR4 Operations identified in } \\
\text { which the right to exercise freedom } \\
\text { of association and collective } \\
\text { bargaining may be at significant } \\
\text { risk, and actions taken to support } \\
\text { these rights }\end{array}$ & 3 & 3 & 3 & 3 & 3 & 3 \\
\hline & & $\begin{array}{l}\text { Percentage of children } \\
\text { working by sector }\end{array}$ & 1 & 1 & 1 & 1 & 1 & 1 \\
\hline & & $\begin{array}{l}\text { GRI HR6 Operations identified as } \\
\text { having significant risk for } \\
\text { incidents of child labour, and } \\
\text { measures taken to contribute to the } \\
\text { elimination of child labour }\end{array}$ & 1 & 1 & 1 & 1 & 1 & 1 \\
\hline & Forced labour & $\begin{array}{c}\text { Percentage (estimate) of forced } \\
\text { labour by region }(\%)\end{array}$ & 1 & 1 & 1 & 1 & 1 & 1 \\
\hline & $\begin{array}{l}\text { Total (without } \\
\text { coefficients) }\end{array}$ & & 12 & 12 & 12 & 12 & 12 & 12 \\
\hline & Total (with coefficients) & & 0.0024 & 0.084 & 12 & 0.0024 & 1.8 & 6.36 \\
\hline \multirow{7}{*}{ Society } & $\begin{array}{l}\text { Public commitment to } \\
\text { sustainability issues }\end{array}$ & $\begin{array}{l}\text { Engagement of sector } \\
\text { regarding sustainability }\end{array}$ & 1 & 1 & 1 & 1 & 5 & 5 \\
\hline & \multirow{3}{*}{$\begin{array}{l}\text { Prevention and mitigation } \\
\text { of conflicts }\end{array}$} & $\begin{array}{l}\text { Is the organization doing business } \\
\text { in a region with ongoing conflicts? }\end{array}$ & 7 & 3 & 3 & 7 & 3 & 7 \\
\hline & & $\begin{array}{l}\text { Is the organization doing business } \\
\text { in a sector that features linkages } \\
\text { to conflicts? }\end{array}$ & 3 & 3 & 3 & 3 & 3 & 7 \\
\hline & & $\begin{array}{l}\text { Is the organization doing business } \\
\text { in a sector otherwise linked to the } \\
\text { escalation or de-escalation } \\
\text { of conflicts? }\end{array}$ & 3 & 3 & 3 & 3 & 3 & 7 \\
\hline & $\begin{array}{c}\text { Contribution to economic } \\
\text { development }\end{array}$ & $\begin{array}{l}\text { Relevance of the considered sector } \\
\text { for the (local) economy }\end{array}$ & 3 & 3 & 3 & 3 & 3 & 1 \\
\hline & $\begin{array}{c}\text { Total (without } \\
\text { coefficients) }\end{array}$ & & 17 & 13 & 13 & 17 & 17 & 27 \\
\hline & Total (with coefficients) & & 0.0034 & 0.091 & 13 & 0.0034 & 2.55 & 14.31 \\
\hline
\end{tabular}




\subsection{Aggregation before and after Change}

Figures 3 and 4 illustrate the aggregation of the hotspot and site-specific indicator results based on the scoring scheme and activity variables. Because of the Zero Brine project, an improved societal performance is expected mainly towards workers and local community groups on the hotspot level (see Figure 3), and workers and society on the site-specific level (see Figure 4). Aggregating impact scores in Figure 3 show that the social performance can improve by $60 \%$ on average due to Zero Brine. In Figure 4, the difference in performance when activity variables are considered is larger than without them. In addition, the DW company is the stakeholder with the larger activity variable coefficient. Therefore, this shows that the DW company performs relatively better than the other companies of the Zero Brine system. These results are in agreement with Di Noi et al. [79] who concluded that workers and local community were mainly affected due to mining operations. Due to regulation, workers and local community are greatly affected similarly to what our results show about Russia and the Russian mining company. In addition, Figure 4 shows that the use of activity variables does not result in changes in most impacted stakeholder groups. Society and workers remain the most impacted, and the impact on value chain actors becomes negligible (in terms of score) because of the Zero Brine project. However, would this change have any effect on the Russian workers' and local community's wellbeing as SLCA results suggest? We believe that, contrary to LCA where a change in the system can result in environmental benefits, a change in SLCA may not result in the expected societal benefits due to the much larger geographical boundaries of the system under study. On the other hand, similar to LCA where a change can result in environmental benefits, but it may not be implemented due to cost, for SLCA, a change would not mean that consumers of magnesium or salt will select the Zero Brine project's recovered materials for purchasing a more socially sustainable product. Typically, the market is influenced by cost and revenue. In the case of magnesium, since the European Union aims for conflict-free sourcing minerals, the SLCA results can become highly beneficial for the magnesium distributor company, while, in the case of salt, the societal performance of Chlor-Alkali 1 is on par with the DW company. Therefore, the SLCA results may be useful for promotion purposes.

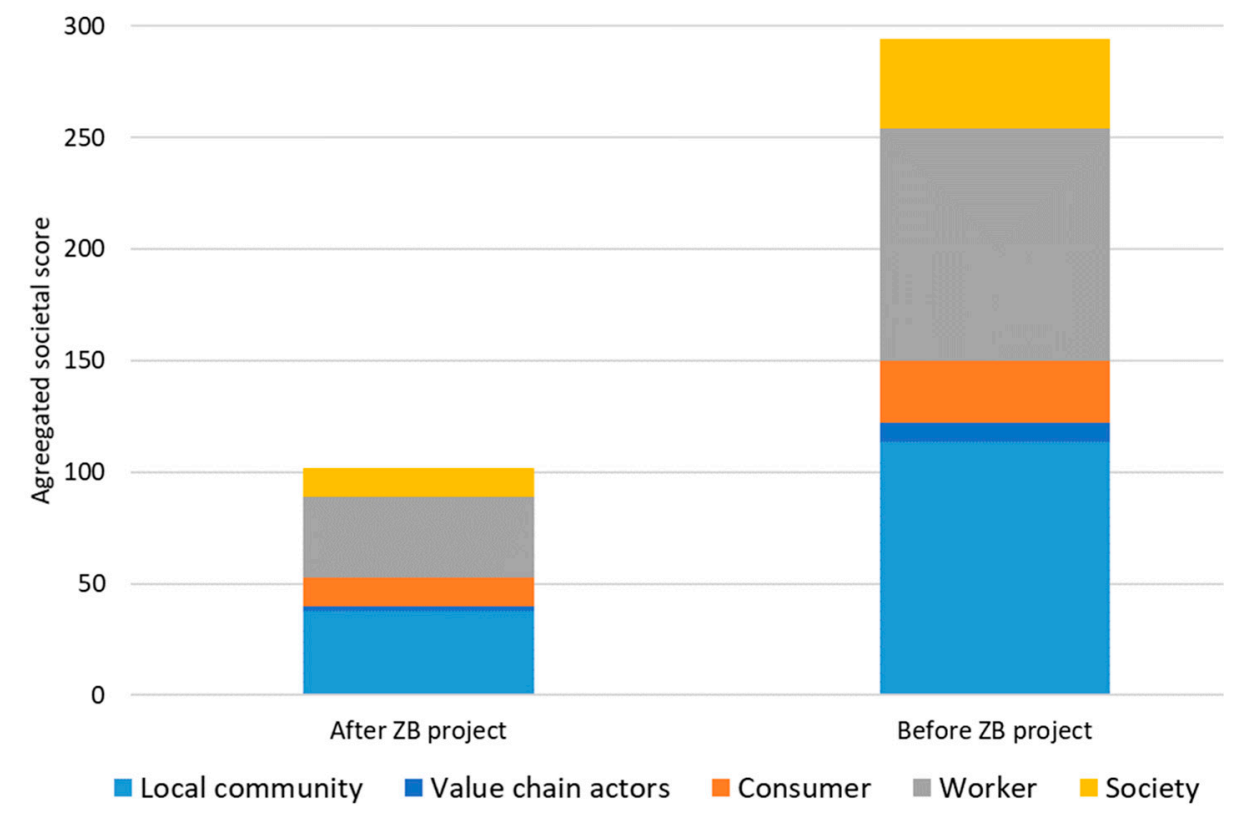

Figure 3. Aggregated hotspot results. 


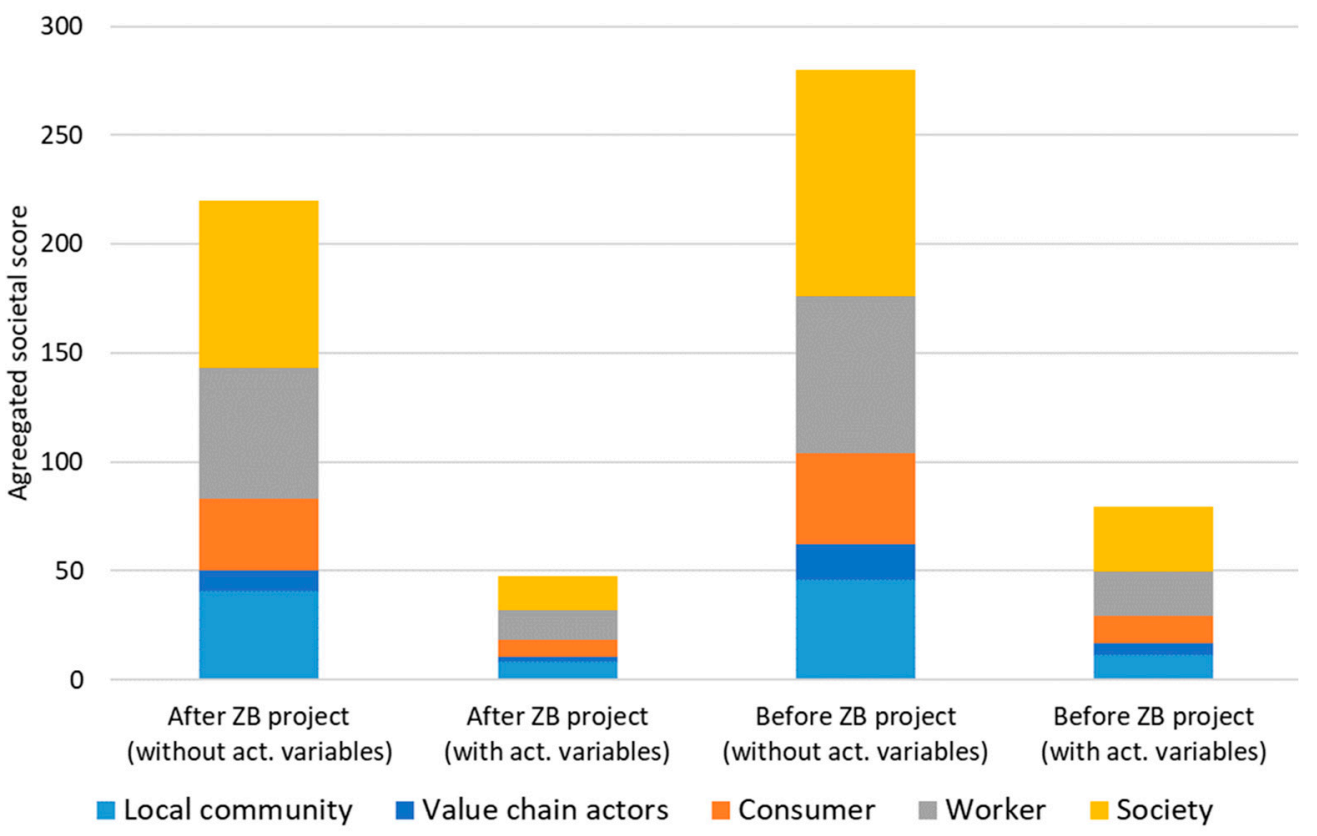

Figure 4. Aggregated site-specific results with and without activity variables.

\section{Conclusions}

This study discusses and attempts to use the consequential SLCA approach on the hotspot and site-specific analysis levels to quantify, for the first time, the societal effects of recovering magnesium and salt to reduce their import from Russia and supply from the northern Netherlands, respectively. Applying the SLCA method on the hotspot analysis level results in comparing mostly the two countries, Netherlands and Russia. The performance due to the Zero Brine project results in societal benefits on both levels of analysis, especially in indicators such as "Freedom of association and collective bargaining", "Fair salary", and "Health and Safety". However, this does not mean that the Russian community and workers will benefit. This is emphasized when applying the consequential SLCA on stakeholders of the value chain. Subsequently, the consequential SLCA may provide more clear benefits when it concerns internal operation of a specific stakeholder.

The main challenges of applying the SLCA method in the Dutch and Russian process industry context were the selection of system boundaries, the conversion of qualitative, and semi-quantitative data with the scoring system, and the up-to-date data collection for Russia and the Russian mining company. Data collection from Dutch companies via interviews was faster, but this fact was also related to the extent of system boundaries. In general, data collection was time-intensive, and the amount of existing indicators results in prioritization or exclusion by the SLCA practitioner. In addition, the use of a scoring system inserts uncertainty in terms of converting qualitative data to quantitative data, yet this is something that cannot be avoided if quantification is required. The use of coefficients is recommended when dealing with multi-actor systems in SLCA as they can scale down or emphasize specific actors. The applied scaling system may result in numeric differences between the two countries and among the different companies. However, these differences sometimes are just a result of the scaling system and their significance should not be misinterpreted. A shorter scaling system is recommended in future studies.

Reducing import of Russian magnesium results in benefits due to reducing the dependence of the Netherlands on Russia. Following from the presented analysis, the Netherlands offers a better and more transparent environment for people and companies than Russia does. Furthermore, decoupling a critical mineral from open pit mining and an industry operating in a country high in conflict with inadequate environmental regulation offers additional benefits that are aligned with the European Union targets. Reducing high-purity salt supply to the DW company does not result in societal benefits. 
Additionally, reducing magnesium imports and high-purity salt supply would not influence how the Russian mining company and the chlor-alkali company operate.

The consequential SLCA can be considered a suitable, yet complex, tool that decision makers can use. However, the effect of the change is not as straightforward as in LCA. In addition, consequential SLCA results can be used from companies for product promotion purposes, but it is not certain that a more socially sustainable magnesium recovery would increase revenue. Nevertheless, we suggest that decision makers in the DW company consider recovering clean water and salt and those in the magnesium distributor company consider distributing magnesium due to expected societal benefits. We recommend that future SLCA studies in the Dutch process industry use the social hotspot database for identifying international hotspots in the supply chain while using only a limited set of indicators based on the study's context and focus on "Local community", "Workers", and "Society" stakeholder groups.

Supplementary Materials: The following are available online at http://www.mdpi.com/2071-1050/11/21/5945/s1, Table S1: SLCA coefficients for Table 2 of manuscript; Table S2: Magnesium distributor imports in the Netherlands based on Russian mining company production and AkzoNobel's production.

Author Contributions: The work is conceived by G.A.T. and G.K. and supervised by G.K., G.A.T. worked on the literature review and data collection, and wrote the original draft as a report. Both authors contributed towards the preparation and review of the manuscript.

Funding: This research was funded by H2020. grant number [No 730390].

Acknowledgments: This work is part of the activities carried out in the framework of the H2020 European project Zero Brine (ZERO BRINE-Industrial Desalination-Resource Recovery - Circular Economy) project under grant agreement No. 730390. The authors would like to thank Jan Willem Mulder and Wilbert van den Broek from Evides Industriewater B.V., Cristinel Degeratu from Europiren B.V. and Thijs de Groot from AkzoNobel N.V. for participating in interview sections. The authors would like to thank the three anonymous reviewers and academic editor for helping to improve this manuscript based on their feedback and Lia Marvakis for English proofreading.

Conflicts of Interest: The authors declare no conflict of interest.

\section{References}

1. European Commission. Report on Critical Raw Materials for the EU. Report of the Ad hoc Working Group on Defining Critical Raw Materials; Ref. Ares (2015)1819503; European Commission: Brussels, Belgium, 2014; pp. 1-41.

2. Skoczko, I. Efficiency estimation of water purification with various filtration mate. Desalin. Water Treat. 2018, 134, 99-108. [CrossRef]

3. The European Parliament and the Council of the European Union. Directive 2008/98/Ec of the European Parliament and of the Council of 19 November 2008 on Waste and Repealing Certain Directives; Official Journal of the European Union: Brussels, Belgium, 2008.

4. Pérez-González, A.; Urtiaga, A.M.; Ibáñez, R.; Ortiz, I. State of the art and review on the treatment technologies of water reverse osmosis concentrates. Water Res. 2012, 46, 267-283. [CrossRef] [PubMed]

5. Bourguignon, D. Circular Economy Package. Four Legislative Proposals on Waste; EPRS|European Parliamentary Research Service: Brussels, Belgium, 2016.

6. Joint Research Center (JRC). Critical Raw Materials and the Circular Economy; Joint Research Center (JRC): Luxembourg, 2017; pp. 1-102.

7. European Commission. Study on the Review of the List of Critical Raw Materials. Final Report; European Commission: Brussels, Belgium, 2017.

8. Sajid Hussain, I.; Head, O.M. Case Study of a Zero Liquid Discharge facility in Textile Dyeing Effluents at Tirupur. 2012. Available online: http://seip.urban-industrial.in/live/hrdpmp/hrdpmaster/igep/content/ e48745/e49028/e51431/e51468/SajidHussain.pdf (accessed on 20 October 2019).

9. Panagopoulos, A.; Haralambous, K.-J.; Loizidou, M. Desalination brine disposal methods and treatment technologies-A review. Sci. Total Environ. 2019, 693, 133545. [CrossRef] [PubMed]

10. Skoczko, I.; Szatylowicz, E. The analysis of physico-chemical properties of two unknown filter materials. J. Ecol. Eng. 2016, 17, 148-154. [CrossRef] 
11. Riabova, L.A. Social License to Operate for Mining Companies in the Russian Arctic as a Tool for Development of Host Territories. Available online: https://iopscience.iop.org/article/10.1088/1755-1315/302/1/012116/meta (accessed on 20 October 2019).

12. Didyk, V.; Bay-Larsen, I.; Sandersen, H.; Ivanova, L. Sustainability and Mining: The Case of the Kola Peninsula; ResearchGate: Berlin, Germany, 2018.

13. United Nations General Assembly. Resolution A/60/1 Adopted by the General Assembly. 2005 World Summit Outcome; United Nations General Assembly: New York, NY, USA, 2005.

14. Brundtland, G.H. Report of the World Commission on Environment and Development: Our Common Future; United Nations: New York, NY, USA, 1987.

15. Benoît, C.; Norris, G.A.; Valdivia, S.; Ciroth, A.; Moberg, A.; Bos, U.; Prakash, S.; Ugaya, C.; Beck, T. The guidelines for social life cycle assessment of products: Just in time! Int. J. Life Cycle Assess. 2010, 15, 156-163. [CrossRef]

16. Clift, R.; Sim, S.; King, H.; Chenoweth, J.; Christie, I.; Clavreul, J.; Mueller, C.; Posthuma, L.; Boulay, A.-M.; Chaplin-Kramer, R.; et al. The Challenges of Applying Planetary Boundaries as a Basis for Strategic Decision-Making in Companies with Global Supply Chains. Sustainability 2017, 9, 279. [CrossRef]

17. Kühnen, M.; Hahn, R. Indicators in Social Life Cycle Assessment: A Review of Frameworks, Theories, and Empirical Experience. J. Ind. Ecol. 2017, 21, 1547-1565. [CrossRef]

18. UNEP/SETAC Life Cycle Initiative. The Methodological Sheets for Subcategories in Social Life Cycle Assessment (S-LCA); UNEP/SETAC Life Cycle Initiative: Ghent, Belgium, 2013; pp. 1-152.

19. UNEP/SETAC Life Cycle Initiative. Guidelines for Social Life Cycle Assessment of Products. Social and Socio-Economic LCA Guidelines Complementing Environmental LCA and Life Cycle Costing, Contributing to the Full Assessment of Goods and Services within the Context of Sustainable Development; UNEP/SETAC Life Cycle Initiative: Ghent, Belgium, 2009.

20. Weidema, B. ISO 14044 also applies to social LCA. Int. J. Life Cycle Assess. 2005, 10, 381. [CrossRef]

21. Lehmann, A.; Zschieschang, E.; Traverso, M.; Finkbeiner, M.; Schebek, L. Social aspects for sustainability assessment of technologies-Challenges for social life cycle assessment (SLCA). Int. J. Life Cycle Assess. 2013, 18, 1581-1592. [CrossRef]

22. Mathe, S. Integrating participatory approaches into social life cycle assessment: The SLCA participatory approach. Int. J. Life Cycle Assess. 2014, 19, 1506-1514. [CrossRef]

23. Jørgensen, A. Social LCA-A way ahead? Int. J. Life Cycle Assess. 2013, 18, 296-299. [CrossRef]

24. Weidema, B.P.; Pizzol, M.; Schmidt, J.; Thoma, G. Attributional or consequential Life Cycle Assessment: A matter of social responsibility. J. Clean. Prod. 2018, 174, 305-314. [CrossRef]

25. Rugani, B.; Benetto, E.; Igos, E.; Quinti, G.; Declich, A.; Feudo, F. Towards prospective life cycle sustainability analysis: Exploring complementarities between social and environmental life cycle assessments for the case of Luxembourg's energy system. Mater. Tech. 2014, 102, 605. [CrossRef]

26. Kudoh, Y.; Sagisaka, M.; Chen, S.S.; Elauria, J.C.; Gheewala, S.H.; Hasanudin, U.; Romero, J.; Sharma, V.K.; Shi, X. Region-specific indicators for assessing the sustainability of biomass utilisation in East Asia. Sustainability 2015, 7, 16237-16259. [CrossRef]

27. Ren, J.; Manzardo, A.; Mazzi, A.; Zuliani, F.; Scipioni, A. Prioritization of bioethanol production pathways in China based on life cycle sustainability assessment and multicriteria decision-making. Int. J. Life Cycle Assess. 2015, 20, 842-853. [CrossRef]

28. Fontes, J. Handbook for Product Social Impact Assessment; Version 3.0; Roundtable for Social Metrics; PRé Sustainability: Amersfoort, The Netherlands, 2016.

29. Opher, T.; Shapira, A.; Friedler, E. A comparative social life cycle assessment of urban domestic water reuse alternatives. Int. J. Life Cycle Assess. 2018, 23, 1315-1330. [CrossRef]

30. Frederiksen, T. Corporate social responsibility, risk and development in the mining industry. Resour. Policy 2018, 59, 495-505. [CrossRef]

31. Chvileva, T.A.; Golovina, E.I. Publication of reporting of metallurgical companies in context of the concept of corporate sustainable development. J. Ind. Pollut. Control 2017, 33, 926-930.

32. Ravochkin, N.; Shchennikov, V.; Syrov, V. Corporate Social and Ecological Responsibility of Russian Coal Mining Companies. E3S Web Conf. 2017, 21, 04017. [CrossRef]

33. Gulakov, I.; Vanclay, F. Social impact assessment in the Russian Federation: Does it meet the key values of democracy and civil society? Impact Assess. Proj. Apprais. 2018, 36, 494-505. [CrossRef] 
34. Shail, R.; Wall, F.; Varul, M.; Whitbread-Abrutat, P.; Baciu, C.; Ejdemo, T.; Lovric, I.; Udachin, V. Corporate Social Responsibility within the Mining Industry: Case Studies from Across Europe and Russia. In Proceedings of the Aachen International Mining Symposia (AIMS): 5th International Conference, Aachen, Germany, 14-17 June 2011.

35. Kokko, K.; Buanes, A.; Koivurova, T.; Masloboev, V.; Pettersson, M. Sustainable mining, local communities and environmental regulation. Barents Stud. 2015, 2, 50-81.

36. EAO Media.ru Kuldursky Brucite Mine in the Jewish Autonomous Region Increases Production 2016. Available online: https://www.eastrussia.ru/en/news/kuldurskiy-brusitovyy-rudnik-v-eao-v-2018gplaniruet-rasshirenie-proizvodstva/ (accessed on 26 March 2019).

37. East of Russia Analytical Agency. The Border Crossing Point at Pashkovo in the EAO for Export to China Brucite is Planned to be Introduced in 2019. 2018. Available online: https://www.eastrussia.ru/en/news/punktpogranpropuska-pashkovo-v-eao-pod-eksport-v-kitay-brusita-planiruetsya-vvesti-v-2019g/ (accessed on 26 March 2019).

38. Our region-The Far East Personal interview with Alexander Ezhov, Director general of Russian Mining Chemical Comapny LLC 2015. Available online: https://www.eastrussia.ru/material/do-kitaya-zdes-skorobudet-mostom-podat/ (accessed on 26 March 2019).

39. Wu, R.; Yang, D.; Chen, J. Social life cycle assessment revisited. Sustainability 2014, 6, 4200-4226. [CrossRef]

40. Chhipi-Shrestha, G.K.; Hewage, K.; Sadiq, R. "Socializing" sustainability: A critical review on current development status of social life cycle impact assessment method. Clean Technol. Environ. Policy 2015, 17, 579-596. [CrossRef]

41. Macombe, C.; Leskinen, P.; Feschet, P.; Antikainen, R. Social life cycle assessment of biodiesel production at three levels: A literature review and development needs. J. Clean. Prod. 2013, 52, 205-216. [CrossRef]

42. Griesshammer, R.; Buchert, M.; Gensch, C.-O.; Hochfeld, C.; Manhart, A.; Reisch, L.; Rüdenauer, I. PROSA_Product Sustainability Assessment Guideline; Öko-Institut e.V.: Breisgau, Germany, 2007.

43. Hunkeler, D. Societal LCA Methodology and Case Study (12 pp). Int. J. Life Cycle Assess. 2006, 11, $371-382$. [CrossRef]

44. Martínez-Blanco, J.; Lehmann, A.; Muñoz, P.; Antón, A.; Traverso, M.; Rieradevall, J.; Finkbeiner, M. Application challenges for the social Life Cycle Assessment of fertilizers within life cycle sustainability assessment. J. Clean. Prod. 2014, 69, 34-48. [CrossRef]

45. Di Noi, C.; Ciroth, A.; Mancini, L.; Eynard, U.; Pennington, D.; Blengini, G.A. Can S-LCA methodology support responsible sourcing of raw materials in EU policy context? Int. J. Life Cycle Assess. 2019. [CrossRef]

46. European Commission. Raw Materials Information System (RMIS): Towardsv2.0—An Interim Progress Report $\mathcal{E}$ Roadmap; Publications Office of the European Union: Luxembourg, 2017.

47. Institute for Economics \& Peace. Global Peace Index 2018: Measuring Peace in a Complex World; Institute for Economics \& Peace: Sydney, Australia, 2018.

48. World Intellectual Property Organization Country Profile: Netherlands. Available online: http://www.wipo. int/members/en/contact.jsp?country_id=130 (accessed on 9 August 2018).

49. The World Economic Forum. World Economic Forum. 2018. Available online: https://www.weforum.org/ (accessed on 9 August 2018).

50. United States Department of State-Bureau of Democracy, Human Rights, and Labor. Russia 2017 Human Rights Report; Country Reports on Human Rights Practices for 2017: Washington, DC, USA, 2017.

51. Amnesty International. Amnesty International Report 2017/18. The State of the World Human Rights; Amnesty International: London, UK, 2018.

52. International Resource Panel. Global Material Flows Database. 2018. Available online: https://www. resourcepanel.org/ (accessed on 10 December 2018).

53. Mangen, M.J.; Friesema, I.H.M.; Pijnacke, R.; Mughini Gras, L.; van Pelt, W. Disease Burden of Food-Related Pathogens in the Netherlands, 2017; RIVM: Bilthoven, The Netherlands, 2018.

54. World Bank. World Bank Group —International Development, Poverty, E Sustainability; World Bank: Washington, DC, USA, 2018.

55. Schwab, K. The Global Competitiveness Report 2016-2017; Insight Report; World Economic Forum: Geneva, Switzerland, 2016.

56. CSR Netherlands. International CSR in the Dutch Chemical Sector; CSR: Utrecht, The Netherlands, $2015 ;$ p. 58. 
57. Privacy International. National Privacy Ranking 2007-Leading Surveillance Societies Around the World; Privacy International: London, UK, 2007.

58. The Law Library of Congress. Global Legal Research Center Government Services Feedback Practices in Selected Jurisdictions; The Law Library of Congress: Washington, DC, USA, 2017.

59. Global Reporting SDD—GRI Database. 2018. Available online: https://database.globalreporting.org/ (accessed on 26 March 2019).

60. ECOLEX The Gateway to Environmental Law. 2018. Available online: https://www.ecolex.org/ (accessed on 19 May 2019).

61. International Labour Organization. National Labour Law Profile; International Labour Organization: Geneva, Switzerland, 2011.

62. Global Slavery Index. The Global Slavery Index 2016; Global Slavery Index: Nedlands, Australia, 2016.

63. U.S. Department of State. Country Reports on Human Rights Practices for 2017; U.S. Department of State Diplomacy in Action; U.S. Department of State: Washington, DC, USA, 2017.

64. Countryeconomy.com NMW-National Minimum Wage 2019. Available online: https://countryeconomy. com/national-minimum-wage (accessed on 26 March 2019).

65. United Nations. UN Gender Statistics; United Nations: New York, NY, USA, 2016.

66. World Bank Databank. Data for Netherlands and Russian Federation. Available online: https://data. worldbank.org/?locations=NL-RU (accessed on 26 March 2019).

67. Transparency International Corruption Perceptions Index 2017. Available online: www.transparency.org (accessed on 26 March 2019).

68. Chen, W.; Holden, N.M. Social life cycle assessment of average Irish dairy farm. Int. J. Life Cycle Assess. 2017, 22, 1459-1472. [CrossRef]

69. Dreyer, L.C.; Hauschild, M.Z.; Schierbeck, J. Characterisation of social impacts in LCA. Part 2: Implementation in six company case studies. Int. J. Life Cycle Assess. 2010, 15, 385-402. [CrossRef]

70. Valente, C.; Brekke, A.; Modahl, I.S. Testing environmental and social indicators for biorefineries: Bioethanol and biochemical production. Int. J. Life Cycle Assess. 2018, 23, 581-596. [CrossRef]

71. Holger, S.; Petra, Z.; Josephine, M.; Andrea, S.; Sandra, V.; Jürgen-Friedrich, H. The social footprint of permanent magnet production based on rare earth elements-a social life cycle assessment scenario. Energy Procedia 2017, 142, 984-990. [CrossRef]

72. Evides Waterbedrijf B.V. Annual Report 2017. Available online: https://www.google.com.hk/url?sa=t\&rct= j\&q=\&esrc=s\&source=web\&cd=2\&ved=2ahUKEwjnso3Eiq31AhXiKqYKHUETBmYQFjABegQIARAC\& url=https $\% 3 \mathrm{~A} \% 2 \mathrm{~F} \% 2 \mathrm{Fwww}$.evides.nl\%2F-\%2Fmedia\%2Ffiles\%2Fjaarverslagen\%2Fevides-annual-report2017-summary.pdf\&usg=AOvVaw2-d9dXp3mrGi1z-FEp8z97 (accessed on 20 October 2019).

73. Mulder, J.W.; Evides Industriewater B.V., Rotterdam, The Netherlands. Personal communication, 2018.

74. Van den Broek, W.; Evides Industriewater B.V., Rotterdam, The Netherlands. Personal communication, 2018.

75. De Groot, M.T.; AkzoNobel N.V., Amsterdam, The Netherlands. Personal communication, 2018.

76. ENGIE. 2017 Management Report and Annual Consolidated Financial Statements; ENGIE: La Défense, France, 2018; p. 186.

77. ENGIE. 2016 Integrated Report. A New Vision of the Energy World; ENGIE: La Défense, France, 2017; p. 52.

78. Degeratu, C.; Europiren B.V., Rotterdam, The Netherlands. Personal communication, 2018.

79. Di Noi, C.; Ciroth, A. Environmental and Social Pressures in Mining. Results from a Sustainability Hotspots Screening. Resources 2018, 7, 80. [CrossRef]

(C) 2019 by the authors. Licensee MDPI, Basel, Switzerland. This article is an open access article distributed under the terms and conditions of the Creative Commons Attribution (CC BY) license (http://creativecommons.org/licenses/by/4.0/). 